J. Product. \& Dev., 12(2): 411 - 435( 2007)

\title{
A PROTOCOL FOR MICROPROPAGATION OF Chrysanthemum morifolium, RAMAT. PLANTS.
}

Azza M.S. Arafa

Ornamental Horticulture Dept., Faculty of Agric. , Cairo Univ., Egypt.

\section{ABSTRACT}

An in vitro propagation was carried out at Plant Tissue Culture Laboratory, Agricultural Development System Project (ADSP), Ministry of Agriculture, during the successive seasons of 2004/2005 and 2005/2006, to find out the favorable methodology for in vitro propagation of Chrysanthemum morifolium, Ramat. The results could be summarized in the following:

The largest shoot length and number of leaves /shoot tip or node explants occurred due MS medium supplemented with $0.1 \mathrm{mg} / \mathrm{L} T D Z$, whereas shoot formation (\%) was the best when shoot tips or nodes were subculture in WPM medium supplied with $0.1 \mathrm{mg} / L \mathrm{TDZ}$, but callus formation favoured the $1.0 \mathrm{mg} / \mathrm{l} \mathrm{TDZ}$ on WPM. Application $\mathrm{GA}_{3}$ at $1.0 \mathrm{mg} / \mathrm{L}$ to shoot tips, subculture on MS medium supplemented with $1.0 \mathrm{mg} \mathrm{BA} / L$., resulted the best shoot length, number of leaves as well as shoot and callus formation. Applying 0.5 $\mathrm{mg} / \mathrm{L} T \mathrm{TDZ}$ combined with $2.0 \mathrm{mg} / \mathrm{L}$ IAA to shoot tip explants gave the more number of leaves and shoot formation. While $2.0 \mathrm{mg} / L$ IAA alone on shoot tips resulted the longest shoots. The heaviest callus formation occurred on node explants treated with $0.5 \mathrm{mg}$ TDZ/l.

Shoot tips subculture on MS medium supplemented with $1.0 \mathrm{mg} / \mathrm{l} \mathrm{BA}$ under light intensity of 1000 lux produced the larger number of leaves and shoot length.

Callus formation was the heaviest on node explants under 1000 lux light intensity. The largest number of leaves and shoot length occurred on shoot tips subculture on MS medium supplied with $1.0 \mathrm{mg} / \mathrm{L} B A$ under $24^{0} \mathrm{C}$. But,callus formation was the best on node explants under $17{ }^{\circ} C$. Adding sucrose to MS medium supplemented with $1.0 \mathrm{mg} / L$ BA was the best compared to fructose and glucose as sources of carbon in producing shoot length, number of leaves and callus formation. The highest values of characters occurred due to $20 \mathrm{~g} / \mathrm{L}$ sucrose combined with shoot tip explants. Shoot length and number of leaves/shoot tip or node explants were the largest when treated with $1.0 \mathrm{mg} / L \mathrm{BA}$, combined with $15 \mathrm{~g}$. /L sucrose. Whereas number of shoots on shoot tips, or node explants was the highest at $1.0 \mathrm{mg} / \mathrm{L}$ $B A$ with $10 \mathrm{~g} / L$ sucrose. The $1.0 \mathrm{mg} / \mathrm{L}$ IAA combined with $15 \mathrm{~g} / \mathrm{L}$ sucrose led to the heaviest callus formation. While root length was the longest by $0.1 \mathrm{mg} / \mathrm{L}$ $B A$ combined with sucrose at $10 \mathrm{~g} / \mathrm{L}$. MS medium at 1/2 strength resulted the largest number of roots, root length and root formation, While full strength of MS failed to induce roots. Reducing MS strength caused concomitant decrease 
in the growth; characters shoot length and number of leaves. MS salts medium at full strength gave the largest growth characters.

Key words: In vitro, micro-propagation, thidiazuron (TDZ), benzyl-adenine (BA), silver nitrate $\left(\mathrm{AgNO}_{3}\right)$, chrysanthemum morifolium, light intensity, ssucrose, type of medium-temperature.

\section{INTRODUCTION}

Chrysanthemum (Chrysanthemum morifolium, Ramat), plant is cultivated as an ornamental plant and as a source of pyrethrum. Several factors were found to affect the regeneration potential of plant tissue cultured in vitro. Of these factors, plant growth regulators. Flick et al. (1983) found that the cytokinin /auxin balance was more important for regeneration than the specific hormone utilized. Kushal and Arora (1994) observed the increasing BA level increased number of shoots of chrysanthemum in in vitro, but suppressed their growth. Haq et al (1998) mentioned that callus induction occurred only on MS medium supplemented with BA at 0.5-1.2 $\mathrm{mg} / \mathrm{L}$, but the best callus resulted by $1.2 \mathrm{mg}$. Kumari and Verghese (2003) stated that callus induction was highest in media supplemented with BAP at $2 \mathrm{mg} / \mathrm{L}+\mathrm{NAA}$ at $0.2 \mathrm{mg} / \mathrm{L}$, callus was elongated in media supplemented with GA3 at 5-10 mg / $\mathrm{L}$ and rooting was initiated on the same media after 10-12 days.

Explant type is another important factor affecting regeneration. Kaul et al. (1999) stated that stem explants were superior to leaf explants for Chrysanthemum morfiolium regeneration in vitro. El-Sayed (2005) mentioned that shoot tips explants increased survival percent and shootlet number /explants of Sequoia sempervirens compared to nodal cuttings, in vitro. Tombolato and Costa (1998) concluded that source of carbon (sucrose, glucose and fructose) was very important component in vitro culture media; because of the light energy deficiency and low $\mathrm{CO} 2$ concentration present in vitro conditions. De Faria et al. (2004) assured the importance of sucrose in in vitro culture media, and gained greater increments in plant height and high seedling multiplication of Dendrobium nobile Lindl. When added $60 \mathrm{~g} / \mathrm{L}$ sucrose to culture media.

The present study was achieved to evaluate effects of some types of media, cytokinins (TDZ and BA), auxins (1AA, 1BA), GA 3 , light intensity, temperature and source of carbon (sugars), individually or combined on shoot tip or node explants from Chrysanthemum morifolium, Ramat, under in vitro culture conditions.

\section{MATERIALS AND METHODS}

This work was conducted during the two successive seasons of 2004/2005 and 2005/2006 at Plant Tissue Culture Laboratory, Agricultural Development System Project (ADSP), Ministry of Agriculture.

Shoot tips (2.0 cm. long) from Chrysanthemum moriflorum, Ramat. Plants grown in the nursery of Ornamental Horticulture Department, Faculty of Agriculture, Cairo University, were obtained on $10^{\text {th }}$ November, during both seasons. Shoot tips 
were washed thoroughly under current water for about an hour. The disinfection of shoot tips was accomplished by stirring for 20 minutes in $1.0 \%$ sodium hypochlorite (NaOCL) solution with few drops of tween 20 (polyoxyethlene sorbitan monolaurate) as a welting agent. The disinfected tips were rinsed three times in sterile de-ionized water and blotted to dry on sterilized filter paper before culturing in vitro. Outside tissues, accompained stem portions and leaflets were cut and removed to leave shoot tips at $0.3 \mathrm{~cm}$ long. Five explants were cultured in jar $(200 \mathrm{ml})$ containing $40 \mathrm{ml}$ of MS (Murashige and Skoog, 1962) medium supplemented with $1.0 \mathrm{mg} / 1 \mathrm{BA}$ (Benzyladenine), as described by Karim et al (2003), for six months. The free contaminated explants were monthly subcultured on similar media. Six months later, shoots were transferred on MS media free hormones for one month to the resulting shoots, which became the source for the following experiments, starting from $15^{\text {th }}$ June 2005 or 2006.

The $1^{\text {st }}$ experiment: Shoot tips, $0.3 \mathrm{~cm}$ long, were cultured on 3 type of media: MS (Murashige and Skoog, 1962) medium, B5 (Gamborg et al, 1968) medium and WPM, Woody Plant Medium (Lloyd and McCown, 1980), supplemented with TDZ (thiodiazuron) at the five levels of $0.0,0.1,0.5,1.0$ and $5.0 \mathrm{mg} / \mathrm{L}$. The same treatments were applied on node explants, $0.3 \mathrm{~cm}$. Combination treatments amounted to 15 (3media and 5 levels of TDZ) were done for each explant. Eight weeks later the data were recoded.

The $2^{\text {nd }}$ experiment was carried out to study the effect of five levels of $\mathrm{GA}_{3}$ (Gibberellic acid) at $0.5,1.0,2.0,4.0$ and $6.0 \mathrm{mg} / 1$ on shoot tip or node explants $(0.3 \mathrm{~cm}$ long) subcultured on MS medium supplemented with $1.0 \mathrm{mg} / 1$ BA. Ten treatments $\left(5 \mathrm{GA}_{3}\right.$ levels and 2 explants) were applied in this experiment, which lasted for 6 weeks.

The $3^{\text {rd }}$ experiment was undertaken to detect the influence of $2.0 \mathrm{mg} / \mathrm{L}$ IAA combined with two levels $(0.5$ and $5.0 \mathrm{mg} / \mathrm{L})$ of TDZ or BA on $0.3 \mathrm{~cm}$ long shoot tip or node explants. This experiment included ten treatments (5 levels of growth substances and 2 types of explants). After six weeks the following data were obtained for the three aforementioned experiments: shoot length $(\mathrm{cm})$, number of leaves, callus formation $(\mathrm{g})$ and shoot formation (\%) /shoot tip or node explants.

The $4^{\text {th }}$ experiment: Shoot tips and nodes $(0.3 \mathrm{~cm}$ long) were cultured on MS medium supplied with $1.0 \mathrm{mg} / \mathrm{L} \mathrm{BA}$ were used to detect the effect of various light intensities (1000, 2000, 3000 at 4000 lux) on shoot length (cm), number of leaves and callus formation $(\mathrm{g})$, after six weeks. The experiment included 8 treatments (4 light intensities with two sources of explants).

The $5^{\text {th }}$ experiment was consummated to test the influence of different degrees of temperature $\left(10,17,24\right.$ and $\left.32^{\circ} \mathrm{C}\right)$ on growth characters of two sources of explants (shoot tip and node, each $0.3 \mathrm{~cm}$ long) cultured on MS medium supplied with $1.0 \mathrm{mg} / 1$ BA. After six weeks, the same data obtained on the foregoing the $4^{\text {th }}$ experiment were recorded.

The $6^{\text {th }}$ experiment was carried out to detect the effect of 3 sugars as different sources of carbon (sucrose, fructose and glucose each at 10, 20, 30 and $40 \mathrm{~g} / \mathrm{L}$ ) on two types of explants (shoot tip and node, $0.3 \mathrm{~cm}$ long) sub-cultured on MS medium 
supplemented with $1.0 \mathrm{mg} / \mathrm{L}$ BA. After six weeks, shoot length $(\mathrm{cm})$, number of leaves and callus formation (g) were recorded. This experiment contained 24 treatments: 12 sugars levels by 2 explants (shoot tip and node), and was done fore one season during $15^{\text {th }}$ June to $31^{\text {st }}$ July 2005.

The $7^{\text {th }}$ experiment was conducted to find out the influence of IAA and IBA auxins each at 0.1 and $1.0 \mathrm{mg} / \mathrm{L}$ levels combined with sucrose at the levels of 5.0, 10.0 and $15.0 \mathrm{~g} / \mathrm{L}$ on $0.3 \mathrm{~cm}$ shoot tip or node explants, individually. The experiment consisted of 12 treatments ( 4 auxins levels by 3 levels of sucrose) for every source of explants. After six weeks, shoot length $(\mathrm{cm})$, number of leaves, root length $(\mathrm{cm})$, number of shoots, and callus formation $(\mathrm{g})$ were assessed.

The $8^{\text {th }}$ experiment was carried out on $15^{\text {th }}$ June 2005 , for one season only in order to evaluate the influence of MS salts at full, three quarter, half and quarter strengths on some root and growth characters. The experiment continued for four weeks when such parameters were assessed: root formation (\%), number of roots, root and shoot length and number of leaves/ shoot tip.

All experiments except the $6^{\text {th }}$ one were carried out during the two seasons. The layout of the eight experiments, except the $8^{\text {th }}$ one were completely randomized factorial with three replications, whereas the eight experiment was complete randomized blocks, with three replications. The averages data were subjected to statistical analysis of variance procedure, in case of zero and percentage value, the original data were firstly arcsine-transformed prior to statistical analysis and the values of L.S.D. were obtained whenever the calculated "F" value were significant at 5\% level (Snedecor and Cochran, 1984).

\section{RESULTS AND DISCUSSION}

The $1^{\text {st }}$ experiment: Effect of three types of media and TDZ (Thidiazuron) levels on some growth characters and calls formation from shoot tips or node explants.

Data shown in Tables $(1 \mathrm{a} \& \mathrm{~b}$ and $2 \mathrm{a} \& \mathrm{~b})$ indicated that the results on shoot tip and node explants were nearly close. The $0.1 \mathrm{mg} / \mathrm{L}$ TDZ (Thidiazuron) level resulted the longest and the more percentage of shoot formation, while number of leaves and callus formation were largest at $1.0 \mathrm{mg} / \mathrm{L}$ TDZ. Such increases were significant compared to most other treatments. MS medium significantly produced the largest length of shoots and number of leave (Figure1); whereas the WPM (Wood Plant Medium) was significantly the best medium for callus and shoot formation on shoot tips as well as on node explants these results are in agreement with those obtained by Ipekci et al, (2001) on Paulowina elongata; Nassar et al, (2001) on Bixa orellana, L and Gad,Mervat and Shehata(2003) on Quercus robur, L.

In the first season, the interaction between TDZ levels and type of media, showed that the $0.1 \mathrm{mg} / \mathrm{L}$ TDZ level supplemented to MS significantly resulted the longest shoots ( $3.27 \mathrm{~cm}$ on shoot tip and $7.04 \mathrm{~cm}$ on nodes) and the largest number of leaves (10.10 and 7.90 for shoot tip and node explants, respectively). While callus formation was significantly the heaviest due to $1.0 \mathrm{mg} / 1 \mathrm{TDZ}$ on WPM medium compared to most combination treatments, as it resulted in $2.94 \mathrm{~g}$ from shoot tip and 
2.80 from node explants. But the $0.1 \mathrm{mg} / \mathrm{L}$ TDZ added to WPM was significantly the best treatment for shoot formation which gave 60.0 (7.75) and 54.0 (7.32) for shoot tip and node explants, successively. The second season's results showed same trend as in the first one. Poovaiah et al ( 2006 a \&b) found that ,the highest mean number of shoots per internodes of Mentha spicata on medium MS containing TDZ .

Table 1a: Effect of different type of media and TDZ concentration on shoot length (cm) and number of leaves after 8 weeks from shoot tips of Chrysanthemum morifolium, during two seasons ( 2004/2005 and 2005/2006).

\begin{tabular}{|c|c|c|c|c|c|c|c|c|}
\hline \multirow{3}{*}{$\begin{array}{l}\text { TDZ level } \\
(\mathrm{mg} / \mathrm{L})\end{array}$} & \multicolumn{4}{|c|}{ Shoot length (cm)/shoot tip } & \multicolumn{4}{|c|}{ Number of leaves /shoot tip } \\
\hline & \multicolumn{3}{|c|}{ Type of medium } & \multirow{2}{*}{$\begin{array}{l}\text { Mean } \\
\text { (A) }\end{array}$} & \multicolumn{3}{|c|}{ Type of medium } & \multirow{2}{*}{$\begin{array}{l}\text { Mean } \\
\text { (A) }\end{array}$} \\
\hline & MS & B5 & WPM & & MS & B5 & WPM & \\
\hline \multicolumn{9}{|c|}{$(2004 / 2005)$} \\
\hline 0.0 & 2.71 & 1.47 & 1.78 & 1.98 & 7.35 & 4.30 & 3.50 & 5.05 \\
\hline 0.1 & 3.27 & 1.77 & 2.09 & 2.38 & 10.10 & 5.15 & 4.50 & 6.58 \\
\hline 0.5 & 2.23 & 2.61 & 1.69 & 2.18 & 7.95 & 6.85 & 4.05 & 6.28 \\
\hline 1.0 & 2.95 & 2.13 & 1.67 & 2.25 & 9.40 & 5.80 & 4.75 & 6.65 \\
\hline 2.0 & 3.02 & 1.81 & 2.01 & 2.28 & 9.15 & 5.25 & 4.70 & 6.37 \\
\hline Mean(B) & 2.84 & 1.96 & 1.85 & & 8.79 & 5.47 & 4.30 & \\
\hline \multicolumn{9}{|l|}{ L.S.D 0.05} \\
\hline (A) & 0.25 & & & & 0.53 & & & \\
\hline (B) & 0.20 & & & & 0.41 & & & \\
\hline$(\mathrm{AxB})$ & 0.44 & & & & 0.92 & & & \\
\hline \multicolumn{9}{|c|}{$(2005 / 2006)$} \\
\hline 0.0 & 2.77 & 1.45 & 1.73 & 1.98 & 7.40 & 4.35 & 3.60 & 5.12 \\
\hline 0.1 & 3.23 & 1.80 & 2.06 & 2.36 & 10.05 & 5.15 & 4.55 & 6.58 \\
\hline 0.5 & 2.18 & 2.72 & 1.68 & 2.19 & 7.90 & 6.90 & 3.95 & 6.25 \\
\hline 1.0 & 2.99 & 2.18 & 1.65 & 2.27 & 9.50 & 5.90 & 4.85 & 6.75 \\
\hline 2.0 & 3.08 & 1.89 & 2.03 & 2.33 & 9.10 & 5.40 & 4.60 & 6.37 \\
\hline $\operatorname{Mean}(B)$ & 2.85 & 2.01 & 1.83 & & 8.79 & 5.54 & 4.31 & \\
\hline \multicolumn{9}{|l|}{ L.S.D 0.05} \\
\hline (A) & 0.21 & & & & 0.48 & & & \\
\hline (B) & 0.17 & & & & 0.37 & & & \\
\hline$(\mathrm{AxB})$ & 0.37 & & & & 0.83 & & & \\
\hline
\end{tabular}

The 2nd experiment: Influence of different $\mathrm{GA}_{\underline{3}}$ levels and source of explants on some growth parameters after six weeks.

It appears from data in Table 3 that raising $\mathrm{GA}_{3}$ levels from $1.0 \mathrm{mg}$ up to 6.0 $\mathrm{mg} / \mathrm{l}$ caused significant progressive reduction in shoot length $(\mathrm{cm})$, number of leaves, callus formation $(\mathrm{g})$ and shoot formation (\%). The 1.0mg $\mathrm{GA}_{3}$ level significantly produced the highest values of all parameters, as compared to other levels. For source of explants, shoot tip surpassed than node explants in producing the best growth. The differences between the two sources of explants were significant for both shoot length 
AZZA ARAFA 
AZZA ARAFA

$2 b$ 
Tab 3 
and number of leaves, but did not reach the level of significant for callus or shoot formation. For the interaction treatments shoot tip explants treated with $1.0 \mathrm{mg} / \mathrm{L}$ $\mathrm{GA}_{3}$ significantly produced the highest records of shoot length, number of leaves, callus and shoot formation which were $4.57 \mathrm{~cm}, 7.60,0.88 \mathrm{gm}$ and $66.67 \%$ ,respectively, in the first season and 4.37, 7.50, 0.92 and $73.33 \%$, consecutively, in the second one.

$\mathrm{GA}_{3}$ stimulated shoot elongation but not shoot bud proliferation of Chrysanthemum morifolium, Karim et al (2003). Kumari and Varghese (2003) on capitulum explants of Chrysanthemum morifolium, stated that calluses elongated in media supplemented with $\mathrm{GA}_{3}$ at $5-10 \mathrm{mg} / \mathrm{L}$, and rooting was initiated on the same media after 10-12 days.

The 3rd experiment: Influence of IAA added to some BA or TDZ levels and source of explants on some growth parameters after six weeks.

Data shown in Table 4 revealed that $2.0 \mathrm{mg} / \mathrm{l}$ IAA individually, significantly produced the longest shoots; but number of leaves and callus formation ( $\mathrm{g}$ ) were significantly improved by $2.0 \mathrm{mg} / \mathrm{L}$ IAA with $0.5 \mathrm{mg} / \mathrm{L} \mathrm{TDZ}$ treatment during both seasons, whereas number of shoots were raised due to $5.0 \mathrm{mg} / \mathrm{L} \mathrm{BA}$ added to $2.0 \mathrm{mg}$ /L IAA treatment in the first season and $0.5 \mathrm{mg} / \mathrm{L} \mathrm{TDZ} \mathrm{with} \mathrm{IAA} \mathrm{treatment} \mathrm{in} \mathrm{the}$ second one.

Shoot tip explants was significantly better than node explants for shoot length $(\mathrm{cm})$, number of leaves and shoots, but callus formation $(\mathrm{g})$ was significantly heavier when explants was taken from node.

Concerning interaction treatments, the longest shoots $(4.63$ and $3.23 \mathrm{~cm}$, in both seasons, successively) resulted by the $2 \mathrm{mg} / 1$ IAA added to shoot tip explant. The largest numbers of leaves were 13.25 and 14.00 at the first and second seasons, consecutively, produced by shoot tip explant supplied with $2 \mathrm{mg}$ IAA /L plus $0.5 \mathrm{mg}$ $/ \mathrm{L}$ TDZ. But the heaviest callus formation $(5.62$ and $5.68 \mathrm{~g}$ in both seasons, respectively) occurred due to IAA and $0.5 \mathrm{mg} / \mathrm{L}$ TDZ cultured from node explant. Number of shoots was more by node explant supplemented with $2.0 \mathrm{mg} / \mathrm{lAA}$ and $\mathrm{TDZ}$ at $0.5 \mathrm{mg} / \mathrm{L}$, in the first season and $5.0 \mathrm{mg} / \mathrm{L}$ in the second one.

Such results disagree with those of Amin et al,(1997)demonstrated that axillary and adventitious bud multiplication of chrysanthemum was possible from the nodal, shoot tip and petiole explants .Haq et al (1998) on chrysanthemum, stated that good callus induction occurred on shoot explants cultured on MS medium supplemented with $1.2 \mathrm{mg} / \mathrm{L}$ IBA. Kaul et al (1999) on chrysanthemum stem explant surpassed leaf explants. Karim et al (2003) reported that shoot multiplication of Chrysanthemum morifolium was achieved from the nodal and shoot tip explants of mature plant using MS medium with BA. El-Sayed (2005) noted that shoot tips of Sequoia semperivens increased shootlet number explant compared to nodal cuttings in in vitro. Poovaiah et al(2006a) showed that maximum number of shoots of Mentha spicata was observed when internodes were used as explant source. 
Tab 4 present 
The $4^{\text {th }}$ experiment: Influence of different light intensities and source of explants on some growth parameters and callus formation (g), after six weeks.

It is clear from data in Table 5 that increasing light intensity led to gradual reduction in the three parameter under study, however such decrease was not significant for both shoot length $(\mathrm{cm})$ and number of leaves, while 1000 lux intensity significantly heaviest callus formation, in both seasons

Nower, (2002) found that light intensity at 2000 lux and photoperiod at $24 \mathrm{hr}$., significantly increased the fresh weight, shoot length ,number of shoots of Lilium and Gladiolus. Shoot tip explant significantly surpassed the node one for improving shoot length and number of leaves, but callus formation showed the reverse. Shoot tip explant under 1000 lux light intensity significantly produced the longest shoots and number of leaves $(1.48 \mathrm{~cm}$ and 12.4 , respectively, in the first season and $1.36 \mathrm{~cm}$ and 11.2, consecutively, in the second one) compared to most other treatments. Whereas, the node explant subjected to 1000 lux intensity treatment resulted the heaviest callus formation (3.00 and 2.75g in both seasons, successively). Such results coincide with the findings of Zhi and Gao (2004) on Chrysanthemum morifolium ,found that the most suitable explant for tissue culture was the shoot tips with a diameter of $0.3 \mathrm{~mm}$., and El-Sayed (2005) observed that shoot tips explant of Sequoia sempervirnes increased shootlet number compared to nodal explant in vitro conditions.

The $5^{\text {th }}$ experiment: Influence of different temperature degrees and source of explants on some growth parameters and callus formation (g), after six weeks.

Subjecting chrysanthemum explants to $24^{\circ} \mathrm{C}$ significantly increased shoot length compared to most other degrees (Table 6). But, number of leaves and callus formation $(\mathrm{g})$ were significantly increased by the $17^{\circ} \mathrm{C}$ as compared to most degrees. The differences between shoot length $(\mathrm{cm})$ and number of leaves values as a result of sources of explants did not reach the level of significance. Node explant significantly improved callus formation $(\mathrm{g})$ than shoot tip. The shoot tip explant subjected to $24^{\circ} \mathrm{C}$ significantly resulted the longest shoots $(1.26$ and $1.64 \mathrm{~cm}$, in the two seasons, respectively) compared to most treatments of combination. The larger number of leaves occurred significantly due to node explant under $17^{\circ} \mathrm{C}$, in the first season $(5.64$ leaf) but resulted in the second on by the shoot tip explant under $24^{\circ} \mathrm{C}$ (5.60 leaf). Callus formation $(\mathrm{g})$ was significantly the biggest: $1.84(1.25) \mathrm{g}$ in the first season and $1.46(1.10) \mathrm{g}$ in the second one, under node explant subjected to $17^{\circ} \mathrm{C}$ combined treatment in both seasons.

\section{The $6^{\text {th }}$ experiment: Influence of some kinds of sugars as a source of carbon at different levels on some growth parameters and callus formation.}

It is evident from data in Table 7 that using sucrose as a source of carbon in MS medium supplemented with $1.0 \mathrm{mg} / \mathrm{L}$ BA surpassed other kinds of sugars, whereas glucose resulted the lowest results and failed to induce callus formation. The sucrose at $20 \mathrm{~g} / \mathrm{L}$, produced the highest record of shoot length $(\mathrm{mm})$, number of leaves and callus formation (g) as compared to all other treatments Figure 1.Callus formation was significantly improved with shoot tip culture in comparison to node as the explants. 
While the differences between shoot length and number of leaves due to source of explants did not reach the level of significance. Applying sucrose at $20 \mathrm{~g} / \mathrm{L}$ level to shoot tip explant significantly resulted the longest shoots $(4.07 \mathrm{~cm})$ and the largest number of leaves (8.07) and the heaviest callus $(2.97 \mathrm{~g})$ compared to all other treatments.

Table 5: Effect of different light intensities and source of explants on shoot length $(\mathrm{cm})$, number of leaves and callus formation (g) after 6 weeks of Chrysanthemum morifolium durig two seasons $(2004 / 2005$ and 2005/2006).

\begin{tabular}{|c|c|c|c|c|c|c|c|c|c|}
\hline \multirow{3}{*}{$\begin{array}{l}\text { Light intensity } \\
\text { (lux) }\end{array}$} & \multicolumn{3}{|c|}{ Shoot length (cm) } & \multirow{2}{*}{\multicolumn{2}{|c|}{$\begin{array}{l}\text { Number of leaves } \\
\text { Source of } \\
\text { explants }\end{array}$}} & \multirow{3}{*}{ Mean } & \multirow{2}{*}{\multicolumn{2}{|c|}{$\begin{array}{l}\text { Callus formation } \\
\text { Source of } \\
\text { explants }\end{array}$}} & \multirow{3}{*}{ Mean } \\
\hline & \multicolumn{2}{|c|}{$\begin{array}{l}\text { Source } \\
\text { explants }\end{array}$} & \multirow{2}{*}{ Mean } & & & & & & \\
\hline & $\begin{array}{l}\text { Shoot } \\
\text { tip }\end{array}$ & Node & & $\begin{array}{l}\text { Shoot } \\
\text { tip }\end{array}$ & Node & & $\begin{array}{l}\text { Shoot } \\
\text { tip }\end{array}$ & Node & \\
\hline \multicolumn{10}{|c|}{$(2004 / 2005)$} \\
\hline 1000 & 1.48 & 0.69 & 1.08 & 12.4 & 6.32 & 9.36 & 0.86 & 3.00 & 1.93 \\
\hline 2000 & 1.24 & 0.88 & 1.06 & 12.0 & 7.68 & 9.84 & 0.71 & 2.25 & 1.48 \\
\hline 3000 & 1.16 & 0.62 & 0.89 & 12.0 & 6.64 & 9.32 & 0.43 & 1.38 & 0.91 \\
\hline 4000 & 0.92 & 0.71 & 0.82 & 10.8 & 6.96 & 8.88 & 0.21 & 0.44 & 0.32 \\
\hline Mean(B) & 1.20 & 0.73 & & 11.80 & 6.90 & & 0.55 & 1.77 & \\
\hline \multicolumn{10}{|l|}{ L.S.D 0.05} \\
\hline (A) & 0.32 & & & 2.51 & & & 0.32 & & \\
\hline (B) & 0.22 & & & 1.78 & & & 0.23 & & \\
\hline$(\mathrm{AxB})$ & 0.45 & & & 3.55 & & & 0.46 & & \\
\hline \multicolumn{10}{|c|}{$(2005 / 2006)$} \\
\hline 1000 & 1.36 & 0.54 & 0.95 & 11.2 & 3.36 & 7.28 & 0.85 & 2.75 & 1.80 \\
\hline 2000 & 0.88 & 0.84 & 0.86 & 9.00 & 7.84 & 8.42 & 0.56 & 2.24 & 1.40 \\
\hline 3000 & 0.88 & 0.50 & 0.69 & 9.40 & 5.96 & 7.68 & 0.35 & 1.40 & 0.87 \\
\hline 4000 & 0.50 & 0.67 & 0.58 & 5.40 & 7.44 & 6.42 & 0.21 & 0.42 & 0.31 \\
\hline Mean(B) & 0.91 & 0.64 & & 8.75 & 6.15 & & 0.49 & 1.70 & \\
\hline \multicolumn{10}{|l|}{ L.S.D 0.05} \\
\hline (A) & 0.40 & & & 3.44 & & & 0.27 & & \\
\hline (B) & 0.29 & & & 2.43 & & & 0.19 & & \\
\hline (AxB) & 0.57 & & & 4.87 & & & 0.38 & & \\
\hline
\end{tabular}

Tombolato and Costa (1998) stated that the source of carbon (sucrose, glucose or fructose) was very important component in in vitro culture media, because of the light energy deficiency and low $\mathrm{CO}_{2}$ concentration in in vitro conditions. Ishil et al (1998) on Phalaenopsis observed that the presence of sucrose in the culture medium cause protocorm formation but its absence caused callus proliferation. While, De Faria et al (2004) noted that sucrose at $60 \mathrm{~g} / \mathrm{l}$ caused the highest increases in plant height and seedling multiplication of Dendrobium nobile in in vitro. The medium type and various carbon sources were markedly influenced in vitro propagation of Eclipta alba Baskaran and Jayabalan(2005). 
AZZA ARAFA

Tab 6 
Table (7): Effect of different sources of carbon levels (sugars) on shoot length (cm), number of leaves, and callus formation (g) after 6 weeks from different source of explants of Chrysanthemum morifolium.

\begin{tabular}{|c|c|c|c|c|c|c|c|c|c|c|}
\hline \multirow{3}{*}{\multicolumn{2}{|c|}{$\begin{array}{l}\text { Sugar levels } \\
(\mathrm{g} / \mathrm{L})\end{array}$}} & \multicolumn{3}{|c|}{ Shoot length (cm) } & \multirow{2}{*}{\multicolumn{2}{|c|}{$\begin{array}{l}\text { Number of leaves } \\
\text { Source of } \\
\text { explants }\end{array}$}} & \multirow{3}{*}{$\begin{array}{l}\text { Mean } \\
\text { (A) }\end{array}$} & \multicolumn{3}{|c|}{ Callus formation (g) } \\
\hline & & \multicolumn{2}{|c|}{$\begin{array}{ll}\begin{array}{l}\text { Source } \\
\text { explants }\end{array} & \text { of } \\
\end{array}$} & \multirow{2}{*}{$\begin{array}{l}\text { Mean } \\
\text { (A) }\end{array}$} & & & & \multicolumn{2}{|c|}{$\begin{array}{c}\text { Source of } \\
\text { explants }\end{array}$} & \multirow{2}{*}{$\begin{array}{l}\text { Mean } \\
\text { (A) }\end{array}$} \\
\hline & & $\begin{array}{l}\text { Shoot } \\
\text { tip }\end{array}$ & Node & & $\begin{array}{l}\text { Shoot } \\
\text { tip }\end{array}$ & Node & & $\begin{array}{c}\text { Shoot } \\
\text { tip }\end{array}$ & Node & \\
\hline \multirow{4}{*}{ Sucrose } & 10 & 2.20 & 2.07 & 2.13 & 5.20 & 4.73 & 4.97 & 1.12 & 0.94 & 1.03 \\
\hline & 20 & 4.07 & 3.97 & 4.02 & 8.07 & 7.83 & 7.95 & 2.97 & 2.77 & 2.88 \\
\hline & 30 & 3.10 & 2.97 & 3.03 & 7.17 & 6.73 & 6.95 & 2.45 & 2.27 & 2.36 \\
\hline & 40 & 2.70 & 2.57 & 2.63 & 6.60 & 6.30 & 6.45 & 1.67 & 1.74 & 1.71 \\
\hline \multirow{4}{*}{ Fructose } & 10 & 1.67 & 1.53 & 1.60 & 3.70 & 3.50 & 3.60 & 0.28 & 0.19 & 0.24 \\
\hline & 20 & 2.30 & 2.17 & 2.23 & 4.30 & 4.30 & 4.30 & 0.52 & 0.49 & 0.50 \\
\hline & 30 & 2.70 & 2.57 & 2.63 & 4.50 & 4.70 & 4.60 & 0.97 & 0.72 & 0.84 \\
\hline & 40 & 2.07 & 1.93 & 2.00 & 4.17 & 3.93 & 4.05 & 0.27 & 0.29 & 0.28 \\
\hline \multirow{4}{*}{ Glucose } & 10 & 0.67 & 0.57 & 0.62 & 2.50 & 2.60 & 2.55 & 0.00 & 0.00 & 0.00 \\
\hline & 20 & 1.30 & 1.20 & 1.25 & 3.37 & 3.17 & 3.27 & 0.00 & 0.00 & 0.00 \\
\hline & 30 & 2.00 & 1.87 & 1.93 & 4.03 & 3.93 & 3.98 & 0.00 & 0.00 & 0.00 \\
\hline & 40 & 1.53 & 1.47 & 1.50 & 3.50 & 3.50 & 3.50 & 0.00 & 0.00 & 0.00 \\
\hline \multicolumn{2}{|l|}{ Mean(B) } & 2.19 & 2.07 & & & 4.76 & 4.60 & & 0.85 & 0.79 \\
\hline $\begin{array}{l}\text { L.S.D 0.0 } \\
\text { (A) } \\
(\mathrm{B}) \\
(\mathrm{AxB})\end{array}$ & & $\begin{array}{l}0.29 \\
\text { N.S. } \\
0.41\end{array}$ & & & & $\begin{array}{l}0.35 \\
\text { N.S. } \\
0.14\end{array}$ & & & $\begin{array}{l}0.09 \\
0.04 \\
0.13\end{array}$ & \\
\hline
\end{tabular}

The 7th experiment: Influence of IAA and IBA auxins and sucrose levels supplemented to shoot tip or node explants on some growth and root parameters.

Data exhibited in Tables ( 8 and 9) revealed that the results of shoot tip attained a parallel trend to those of node explants and the findings at both seasons showed a close trend.

In the first season, growth parameters expressed as shoots number and length as well as number of leaves were significantly increased due to $1.0 \mathrm{mg}$ IBA /L supplementation; while root length significantly favour the lower level of IBA $(0.1 \mathrm{mg}$ $/ \mathrm{L})$, the $0.1 \mathrm{mg} / \mathrm{L}$ IAA gave the lowest values. IAA at $1.0 \mathrm{mg} / \mathrm{L}$ supplement significantly resulted the highest callus formation, whereas IBA at any level gave the lowest formation. Increasing sucrose concentration in media significantly gradually raised shoot and root length, number of leaves and callus formation values. But shoot length was significantly the longest under $10 \mathrm{~g} / \mathrm{L}$ sucrose compared to higher or lower concentrations. Concerning treatments of the interaction between auxins and sucrose levels, it appeared that $1.0 \mathrm{mg} / \mathrm{L} \mathrm{IBA}$ and $15 \mathrm{~g} / \mathrm{L}$ sucrose significantly resulted the longest shoots $(5.03 \mathrm{~cm}$ on shoot tip and $4.63 \mathrm{~cm}$ on node explants) and the largest number of leaves (8.07 and 7.70, upon shoot tip and node explants, respectively). The largest number of shoots ( 3.0 on shoot tip and node explants) was given by 1.0 IBA 
Fig 1 
Tab 8a 
Tab 8b 


\section{Tab 9a}


Tab 9b 
$\mathrm{mg} / \mathrm{L}$ combined with $10 \mathrm{~g} / 1$ sucrose treatment. But root length significantly preferred by the $0.1 \mathrm{mg} / \mathrm{L}$ IBA with $15 \mathrm{~g} / \mathrm{L}$ sucrose, which resulted 8.80 and $8.37 \mathrm{~cm}$ on shoot tip and node explants, consecutively. Callus formation was the heaviest $(1.85 \mathrm{~g})$ on shoot tip and $1.37 \mathrm{~g}$ on node explant) due to IAA at $1.0 \mathrm{mg} / \mathrm{L}$ level combined with 15 $\mathrm{g} / \mathrm{L}$ sucrose.

The results of the second season were similar to those obtained in the first one. Datta et al (2001) on Chryanthemum morifalium, mentioned that shoots in in vitro rooted in $1 / 2 \mathrm{MS}+1.5 \mathrm{~g} / 1$ sucrose $+0.2 \mathrm{mg} / \mathrm{l}$ NAA. Sarker and Shaheen(2001) showed that, roots developed (100\%) on MS medium containing $0.2 \mathrm{mg} / 1 \mathrm{IBA}$ of Chryanthemum morifalium.

The 8th experiment: Influence of MS salts strength on some growth and root parameters, from shoots after four weeks.

Data in Table 10 indicated that MS medium at full strength significantly highest records of the studied growth characters expressed in shoot length and number of leaves, but failed to produce roots. Decreasing MS strength led to progressive reduction in growth characters. The highest root formation, number of roots and root length significantly resulted by MS at half strength in both seasons. These results coincide with the findings of many investigators that reducing the strength of MS medium induced rooting of explants. Kushal and Arora (1994), Datta et al (2001) and Zhi and Gao (2004) on chrysanthemum, stated that rooting characters were the best on half MS strength. While shoot growth of chrysanthemum, in vitro was better 100$150 \%$ on MS (Oliviera et al, 1996).

Table 10: Effect of different MS salts strengths on root formation (\%), number of roots, root length $(\mathrm{cm})$, shoot length $(\mathrm{cm})$ and leaves number after 4 weeks from shoot tips of Chrysanthemum morifolium during two seasons $(2004 / 2005$ and $2005 / 2006)$.

\begin{tabular}{|c|c|c|c|c|c|c|c|c|c|c|}
\hline \multirow{3}{*}{$\begin{array}{l}\text { MS salts } \\
\text { strength }\end{array}$} & \multicolumn{2}{|c|}{$\begin{array}{c}\text { Root formation } \\
(\%)\end{array}$} & \multicolumn{2}{|c|}{$\begin{array}{l}\text { Number of } \\
\text { roots }\end{array}$} & \multicolumn{2}{|c|}{$\begin{array}{l}\text { Root length } \\
\quad(\mathrm{cm})\end{array}$} & \multirow{2}{*}{\multicolumn{2}{|c|}{$\begin{array}{c}\begin{array}{c}\text { Shoot } \\
\text { length } \\
(\mathrm{cm})\end{array} \\
\text { Seasons }\end{array}$}} & \multirow{2}{*}{\multicolumn{2}{|c|}{$\begin{array}{c}\begin{array}{c}\text { Number of } \\
\text { leaves }\end{array} \\
\text { Seasons } \\
\end{array}$}} \\
\hline & & & & sons & & ons & & & & \\
\hline & $1^{\text {st }}$ & $2^{\text {nd }}$ & $1^{\text {st }}$ & $2^{\text {nd }}$ & $1^{\text {st }}$ & $2^{\text {nd }}$ & $1^{\text {st }}$ & $2^{\text {nd }}$ & $1^{\text {st }}$ & $2^{\text {nd }}$ \\
\hline Full & $\begin{array}{l}0.00 \\
(0.16)\end{array}$ & $\begin{array}{l}0.00 \\
(0.16)\end{array}$ & 0.00 & 0.00 & 0.00 & 0.00 & 5.67 & 6.00 & 8.73 & 8.83 \\
\hline $\begin{array}{l}\text { Three } \\
\text { quarter }\end{array}$ & $\begin{array}{l}32.00 \\
(5.65)\end{array}$ & $\begin{array}{l}33.33 \\
(5.78)\end{array}$ & 1.60 & 1.73 & 3.77 & 3.97 & 4.10 & 4.10 & 6.17 & 6.17 \\
\hline Half & $\begin{array}{l}46.67 \\
(6.83)\end{array}$ & $\begin{array}{l}49.33 \\
(7.02)\end{array}$ & 2.33 & 2.47 & 8.80 & 8.50 & 2.50 & 2.53 & 5.50 & 5.60 \\
\hline Quarter & $\begin{array}{l}26.67 \\
(5.16)\end{array}$ & $\begin{array}{l}26.67 \\
(5.16)\end{array}$ & 1.33 & 1.35 & 4.67 & 4.40 & 1.63 & 1.73 & 4.70 & 4.80 \\
\hline L.S.D 0.05 & 0.43 & 0.32 & 0.25 & 0.18 & 0.94 & 0.76 & 0.51 & 0.51 & 0.64 & 0.55 \\
\hline
\end{tabular}




\section{CONCLUSION}

From the previous results it would be concluded that:

- Supplemented 0.1mg/L TDZ to MS medium, increased shoot length and number of shoot /shoot tip or node explant. Callus and shoot formation were the best with WPM medium supplemented with 1.0 and $0.1 \mathrm{mg} / \mathrm{L}$ TDZ, respectively.

- The highest shoot length, number of leaves, callus and shoot formation occurred by $1.0 \mathrm{GA}_{3}$ added shoot tip explant.

- Shoot tip explants supplemented with $0.5 \mathrm{mg} / \mathrm{L} \mathrm{TDZ}$ caused the largest increase in number of leaves and shoots number. While the longest shoot resulted by 2.0 IAA added to shoot tip explant. But callus formation favoured node explant supplied with $0.5 \mathrm{mg} / \mathrm{L}$ TDZ.

- Shoot length and number of leaves were the largest on shoot tip explants illuminated with 1000 lux or put under $24^{\circ} \mathrm{C}$. But callus formation was the best due to node explant subjected to 1000 lux light intensity or $17^{\circ} \mathrm{C}$.

- Shoot tip explant supplied with 20g/l sucrose gave the largest shoot length, number of leaves and callus formation.

- $1.0 \mathrm{mg} / \mathrm{L}$ IBA combined with $15 \mathrm{~g} / 1$ sucrose resulted the largest shoot length, number of leaves and callus formation, but number of shoots favoured $1.0 \mathrm{mg} / \mathrm{L}$ IBA combined with $10 \mathrm{~g} / 1$ sucrose. The longest roots were produced by $0.1 \mathrm{mg} / \mathrm{L}$ IBA with $10 \mathrm{~g} / \mathrm{L}$ sucrose.

Similar results occurred from shoot tip or node explants.

- Rooting characters (formation, length and number) were the largest on half strength of MS (Figure 1). Whereas full MS strength gave the longest shoots and the more number of leaves, but were suppressed as MS strength was reduced.

\section{REFERENCES}

Amin ,M.N .;Azad,M.A.K.;Begum,F. and Islam,M.M. (1997).Micropropagation of Chrysanthemum morifoium through axillary bud and leaf -derived callus culture.Plant Cult.Conf.. , IPSA,Gazipur, Dhaka.Dec. 10 :5.

Baskaran and Jayabalan(2005).An efficient micropropagation system for Eclipta alba-a valuable medicinal herb. In Vitro Cellular and Developmental BiologyPlant ,41 (4): 532-539.

Datta,S.K.; Mandal, A.K. and Saxena, M. (2001). Direct organogenesis from ray and disc florets of a newly evolved chlorophyll variegated chrysanthemum (Chrysanthemum morifoium). Ind. J. Agric. Sci., 71 (10): 655-657.

De Faria, R.T.; Rodrigues, F.N.; Oliviera, L.V.R. and Miiller, C. (2004). In vitro Dendrolium nobile plant growth and rooting in different sucrose concentrations. Hortic. Bras., 22 (4): 149-154.

El-Sayed, H.M.F.(2005). In vitro clonal propagation and preservation of genetic resources of some woody plants. Ph.D. Thesis, Fac. Agric., Cairo Univ.,Egypt. 
Flick, C.E.; Evans ,D.A. and Sharp, W.R.(1983). Organogenesis. In: Handbook of Plant Cell Culture: Evans, D.A; W.R. Sharp, P.V.A mmirato and y.yamada (eds.). 1:13-81. Mc Millan Publ. Co., N.Y.

Gad,Mervat M.A. and Shehata, M.S.(2003).Potentiality of Quercus robur, L. for inducing shootlets mass production through tissue culture techniques and factors influencing it success. J.Agric.Sci. Mansoura Univ., 28 (2)1531-1544.

Gamborg ,O.L.;Miller,R.A. and Ojima,k.(1968).Nutrient requirements of suspension cultures of soybean root cells. Exp. Cell Res., 50:151-158.

Haq, I.; Khan, J. ; Allam, M. and Khattak, M.S. (1998). In vitro culture of chrysanthemum Sarhad .J. Agric., 14 (3): 211-213.

Ipekci, Z. ; Altinkut , A. ;Kazan , K. ; Bajrovic ,K and Gozukirmizi ,N.(2001).High frequency plant regeneration from nodal explants of Paulowina elongata. Plant Biol., 3(2):113-115.

Ishil, Y.; Takamura, T.; Goi, M.and Tanaka, M. (1998). callus induction and somatic embriogenesis of Phalaenopsis. Plant cell Rep., 17: 446-450.

Karim, M.Z. ;Amin ,M.N .;Azad,M.A.K.;Begum,F.;Rahman,M.M.;Islam,M.M.

and Alam, R.(2003).Effects of different plant growth regulature on in vitro shoot multiplication of Chrysanthemum moriflorum.Online J.Bio.Sci, 3(6):553-560.

Kaul, V.; Miller, R.M.; Hutchinson ,J.F. and Richards, D. (1999). Shoot regeneration from stem and leaf explants of Dendranthema grand-iflore Tzvelev (syn. Chrysanthemum moriflorum, Ramat.). Plants Cell, Tissue and Organ Culture, 21 (1): 21-30.

Kumari, M. and Varghese, T.M. (2003). Efficient in vitro regrneration of plantlets from capitulum explants in chrysanthemum cultivars Miss Universe and Snow Ball. J. Ornam. Hort. New Series.,6 (4): 316-321.

Kushal, S. and Arora, J.S. (1994). In vitro multiplication of Chrysanthemum morifolium ,Ramat. cv. Riot. J. Ornam. Hort., 2(1/2): 63-68.

Lloyd, G. and McCown, B. (1980). Commercially feasible- micropropagation of Mountain laurel, Kalmia latifolia by use of shoot- tip culture. Int. Plant prop. Soc. Prog., 30: 421-427.

Murashige, T. and Skoog, F. (1962). Arevised medium for rapid growth and bioassays with tobacco tissue cultures. Physiol. Plant., 15: 473-497.

Nassar,A.H.;Khalifa,S.F.;Hammouda ,F.M. and Shsms,K.A.(2001). In vitro propagation of Bixa orellana, L(annatto), an economically important plant newly introduced to Egypt. Egypt. J. Bot.,41(2):241-253.

Nower,A.A.A. (2002). Studies on production of some ornamental bulbs and establishment of gene transfer system through tissue culture techniques . Ph.D. Thesis., Fac. Agric., Cairo Univ.,Egypt.

Oliveira, P.D. de; Pasqual, M. and Paiva, R. (1996). Effect of different concentrations of MS medium, nitrogen and sucrose on micro- propagation of Chrysanthemum cv. Orange Reagen. Bragantia, 55 (1): 9-18 (Cf. CAB Abstracts, record 45 of 89). 
Poovaiah , C .R .;Weller, S.C. and Jenks ,M .A. (2006a) .In vitro adventitious shoot regeneration of native spearmint using internodal explants. Hort. Science, 41(2):414-417.

Poovaiah , C. R. ;Weller ,S.C. and Jenks ,M .A. (2006b) . A dventitious shoot regeneration of scotch spearmint(Mentha $\mathrm{x}$ Gracilis Sole). In Vitro Cellular and Developmental Biology-Plant, 42 (4):354-358.

Sarker,R.H. and Shaheen,I.(2001).In vitro propagation of chrysanthemum (Chrysanthemum morifolium, Ramat.)through tissue culture. Plant Tissue Cult.,11 (1):85-91.

Snedecor, G.W. and Cochran, W.G. (1984). Statistical Methods. $7^{\text {th }}$ Printing. The lowa State Univ. Press, Ames, Iowa, U.S.A.

Tombolato, A.F.C. and Costa, A.M.M. (1998). Micropropagation of ornamental plants. Tech. Bull, no-174, campinas, Instituto Agronomico, P.72.

Zhi, H. and Gao, S.L. (2004). Tissue culture of shoot tip and in vitro propagation of Chrysanthemum morifolium, Ramat., J. Plant Resources and Envir., 13(1): 2427. 


\title{
بروتوكول الأكثار الاقيق لنباتات الأراولة
}

\author{
عزة محمد سعيد عرفة \\ قسم بساتين الزينة ـ كلية الزراعة - جامعه القاهرة
}

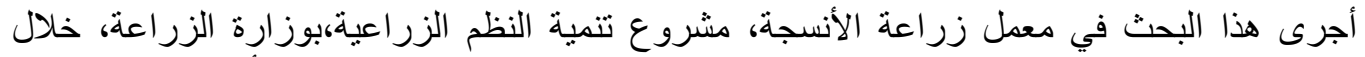

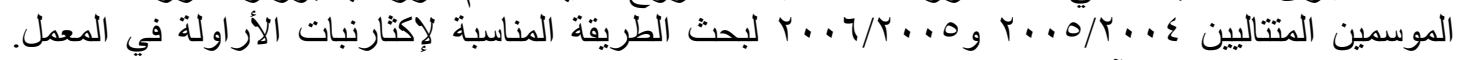
ويمكن إيجاز النتائج في الآتي : الآنين

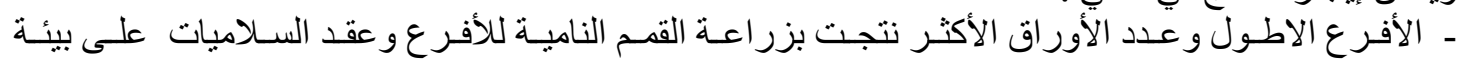

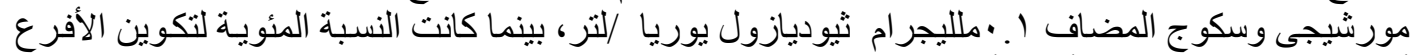

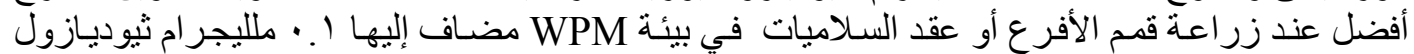

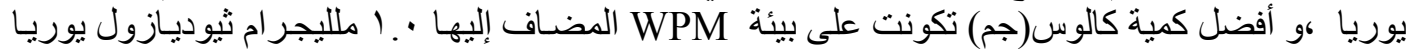

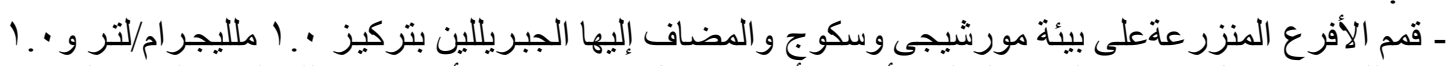

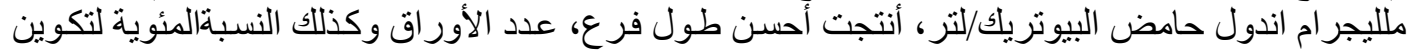

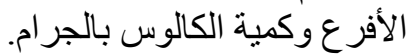

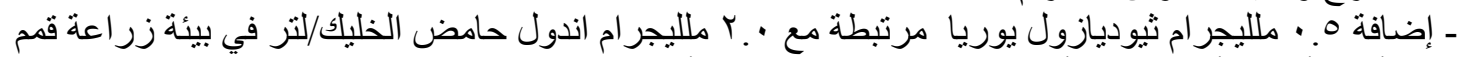

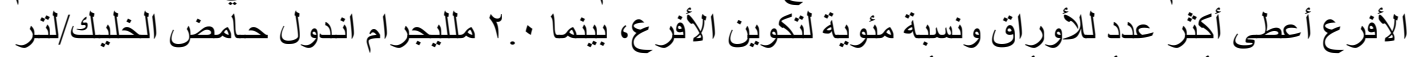

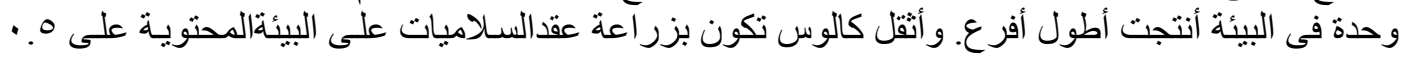

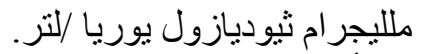

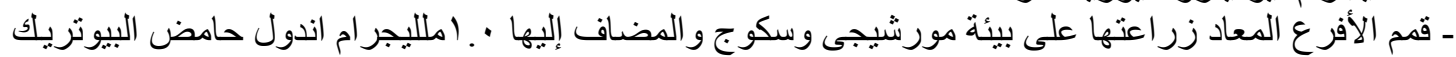

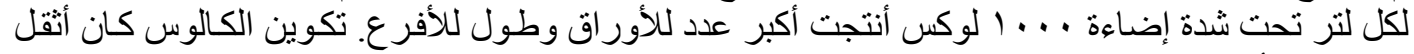

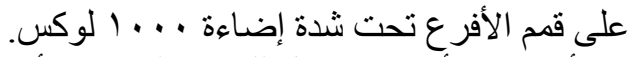

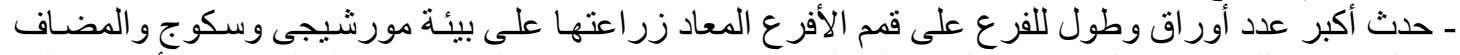

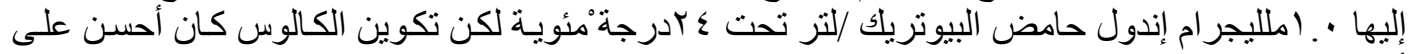

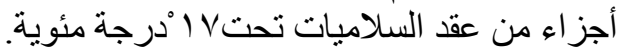

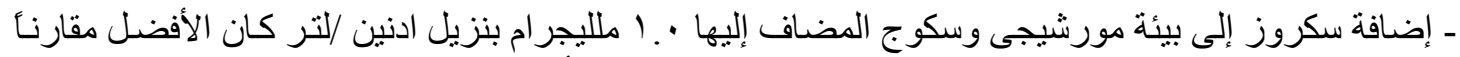

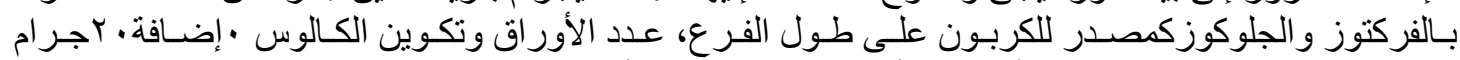

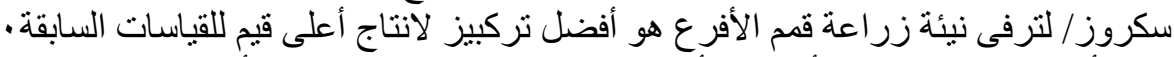

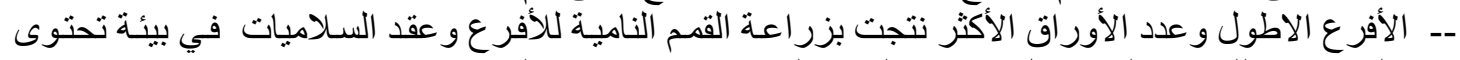

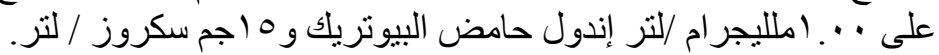

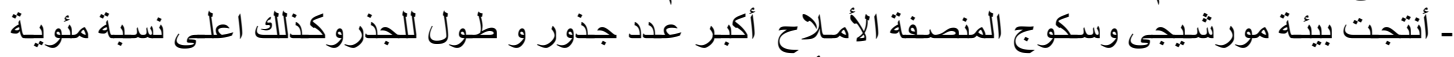

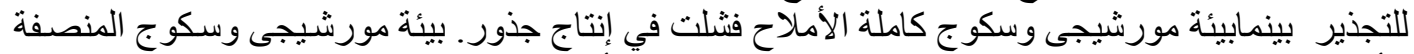

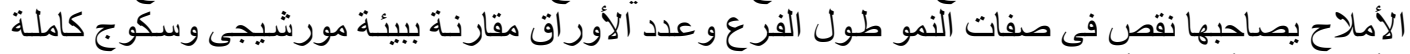

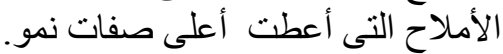

